\title{
Walking Ecosystems in Microbiome-Inspired Green Infrastructure: An Ecological Perspective on Enhancing Personal and Planetary Health
}

\author{
Jake M. Robinson ${ }^{1,2,3,4, * i D}$, Jacob G. Mills ${ }^{4,5}$ iD and Martin F. Breed ${ }^{4,5}$ \\ 1 Department of Landscape, University of Sheffield, Sheffield S10 2TN, UK \\ 2 Improving Wellbeing through Urban Nature (IWUN) Research Group, Sheffield S10 2TN, UK \\ 3 In VIVO Planetary Health, Worldwide Universities Network (WUN), West New York, NJ 10704, USA \\ 4 Healthy Urban Microbiome Initiative (HUMI), Adelaide, SA 5005, Australia; \\ jacob.mills@adelaide.edu.au (J.G.M.); martin.breed@adelaide.edu.au (M.F.B.) \\ 5 School of Biological Sciences and the Environment Institute, the University of Adelaide, Adelaide SA 5005, \\ Australia \\ * Correspondence: jmrobinson3@sheffield.ac.uk
}

Received: 16 October 2018; Accepted: 12 November 2018; Published: 16 November 2018

\begin{abstract}
Principles of ecology apply at myriad scales, including within the human body and the intertwined macro and microscopic ecosystems that we depend upon for survival. The conceptual principles of dysbiosis ('life in distress') also apply to different realms of life-our microbiome, the macro environment and the socioeconomic domain. Viewing the human body as a holobiont-a host plus billions of microbial organisms working symbiotically to form a functioning ecological unit-has the potential to enhance personal and planetary health. We discuss this ecological perspective in our paper. We also discuss the proposals to rewild the microbiome, innovative microbiome-inspired green infrastructure (MIGI) and the basis of prescribing 'doses of nature'. Particular emphasis is given to MIGI - a collective term for the design and management of innovative living urban features that could potentially enhance public health via health-inducing microbial interactions. This concept builds upon the microbiome rewilding hypothesis. Mounting evidence points to the importance of microbial diversity in maintaining favorable health. Moreover, connecting with nature-both physically and psychologically-has been shown to enhance our health and wellbeing. However, we still need to understand the underlying mechanisms, and optimal types and levels of exposure. This paper adds to other recent calls for the inclusion of the environment-microbiome-health axis in nature-human health research. Recognizing that all forms of life-both the seen and the unseen-are in some way connected (ecologically, socially, evolutionarily), paves the way to valuing reciprocity in the nature-human relationship. It is with a holistic and symbiotic perspective that we can begin to integrate strategies and address connected issues of human and environmental health. The prospective strategies discussed in our paper focus on enhancing our connections with the natural world, and ultimately aim to help address the global challenge of halting and reversing dysbiosis in all its manifestations.
\end{abstract}

Keywords: planetary health; microbiome; urban nature; biodiversity; mental health; nature connectedness; green space; Noncommunicable diseases; environmental health; health and wellbeing

\section{Introduction-The Holobiont}

Planet Earth's biosphere supports several biomes, each containing many ecosystems. Each ecosystem supports a diversity of abundant macro-organisms, which in turn harbor a multitude of microscopic life forms - the bacteria, viruses, archaea, and microeukaryotes. Each human being can be thought of as a complex and dynamic ecosystem, supporting billions of microbes that provide 
mutualistic functions [1]. Indeed, human beings can be considered holobionts, from holo-a Greek derivative for the word 'whole', and biont, for 'life' and defined as a host plus billions of stable and transient microbial organisms working symbiotically to form a functioning ecological unit [2].

Not surprisingly, this concept can be difficult to embrace; consciousness as a biological phenomenon is steeped in intrinsic complexities, and it is perhaps easier to view ourselves as an individual of a species. Even as individuals, a fundamental asymmetry exists between how we view ourselves and how we view others, due in part to deeply complex emotional and cognitive immersion [3]. Although this concept may seem counterintuitive when compared to our default perceptions, taking an ecological approach to viewing humans as holobionts can lead to an influx of fascination and curiosity. Importantly, taking an ecological and holistic view of the human body could also make a significant contribution to both personal and planetary health. This perspective is exemplified by the recent calls for principles of ecology to be included in medical curricula [4] - a recognition of the human body as an ecological unit, openly interacting with the environment via complex microscopic processes.

Adopting a holistic philosophical framework, our paper aims to explore these ecological principles in greater detail, whilst highlighting the links between 'human', microbial and environmental health. We also provide an overview of prospective landscape and social interventions that have the potential to enhance our connections with the natural world, through health-inducing microbial interactions and psychosocial pathways. These strategies, namely microbiome rewilding, microbiome-inspired green infrastructure (MIGI), and green prescribing, ultimately aim to make an important contribution to both personal and planetary health. Emphasis is given to MIGI-a collective term for the design and management of innovative living urban features that could potentially enhance public health via health-inducing microbial interactions. This concept builds upon the microbiome rewilding hypothesis.

\section{Interconnectedness and Evolutionary Biology}

There is growing recognition that all forms of life are interconnected, ecologically and evolutionarily $[5,6]$. These tangled connections also traverse the boundaries of the sociosphere-the complex realm of dynamic human-centric structures and interactions that weave their way in and out of our social lives and cultural identities. Indeed, it is the interconnectedness of societal health with environmental stability and resilience that are integral to the concept of planetary health $[7,8]$.

From an evolutionary perspective, this vast array of connections manifest with great depth and diversity. For example, it has recently been hypothesized that the root-leaf axis in plants may be an evolutionary analogue to the gastrointestinal-brain axis in animals [9]. This hypothesis is undoubtedly provocative and draws upon the functional parallels between auxin, a plant hormone, and serotonin, a hormone and neurotransmitter in 'higher animals', and their quantum interactions with photons and nutrients [9].

Following the mid-late 20th century advances in molecular biology, the re-evaluation of evolutionary theory has been a ubiquitous and tantalizing area of interest for evolutionary biologists. It is thought that horizontal gene transfer-that is, the integration of genetic material typically acquired from other species (not vertically transmitted from a parent) - may play a significant role in the evolution of what is traditionally considered to be a species [10]. Quammen explores this topic in his recent book The Tangled Tree [11]. He describes how a substantial proportion of the human genome (roughly $8 \%$ ) was acquired horizontally through viral infections. This, along with the idea of the holobiont, further challenges our conceptual understanding of a species as a discrete entity, and even human identity and individuality.

A classic example of this interspecies molecular nexus that further strengthens the tangled view of evolution, is the existence of mitochondria. These are organelles responsible for synthesising adenosine triphosphate (ATP) via oxidative phosphorylation, producing over $90 \%$ of our cellular energy [12]. However, mitochondria are thought to have evolved from a bacterial progenitor in the Alphaproteobacteria phylum [13]. In summary, not only can human beings be described as functional 
ecological units comprised of microbial symbionts, but approx. $8 \%$ of our genome is of microbial origin. And not only this, the organelles that contribute significantly to our survival, are also microbial in origin. This overturning of the traditional view of the tree of life, along with the realization that the biosphere and sociosphere are inextricably linked, paves the way for a new holistic philosophy of life and health. It could be argued that the natural step that follows this recognition of interconnectedness, is one that explores mutually-advantageous relationships between the constituents of the whole. The whole being the planet, and the constituents being our environments, our societies, our 'selves', our symbionts, and our genes.

\section{Forty-Three Percent Human}

Recent estimates suggest that human cells (i.e., somatic and germ) constitute only $43 \%$ of all the cells that form a human body [14]. Due to advances in genomic technologies, this has changed from earlier estimates of $10 \%$, but in any case, it is still an impressively low figure. The other $57 \%$ of cells are microbial (bacteria, viruses, archaea, microeukaryotes), and therefore, in terms of cell abundance at least, humans are actually more microbial than human. This statement is also true when considering ratios of gene abundance-microbial genes within the human body are thought to outnumber human genes by between 150 and 1000 times [15,16]. With a moment of reflection, this can lead to a medley of existential questions such as-what does it mean to be human?

A study has shown that the average palmar surface on the human hand can harbor $>150$ species-level bacterial phylotypes [17]. To put this into perspective, that is more than the total number of all mammal species that inhabit all of the ecosystems in the UK. However, this is dwarfed by a microbial ecosystem less than $1 \mathrm{~m}$ away in the oral cavity, where approximately 700 species of bacteria form dense interactive networks of conjugated biofilms [18]. This is dwarfed further still by the human gut, which is one of the densest microbial habitats on earth [19], with approximately 1000 species of bacteria (in a 'healthy' gut) and a combined microbial weight of $2 \mathrm{~kg}[20,21]$. Like their macro counterparts, microbial ecologists have an important role in studying the relations of microorganisms to one another and to their environments-the network of habitats and biotic processes that support and are supported by a symbiotic conglomerate, a complex system we refer to as the human body.

Viewing the human body as an ecosystem goes far beyond the apt but quirky analogies such as the 'rainforests of our guts', the 'savannahs of our skin' and the 'coral reefs of our mouths'. There are many macro-ecological parallels; for example, just as plants convert energy from the sun, acquire nutrients from the soil and subsequently provide organisms higher up the food web with health-inducing nutrients and bioactive phytochemicals, the microbes living in the human gut consume the food that we ingest and release important metabolites. For example, Bacteroides spp. are known to convert carbohydrates into short-chain fatty acids (SCFAs), which are essential in maintaining gut homeostasis [22,23]. As Cryan said in his 2017 TEDx talk, "you are what your microbes eat!" [24].

\section{Functional Ecology and Food for Thought}

From a health perspective, it may pay dividends to embrace this holobiotic nature; viewing the 'human' as a dynamic ecosystem that requires stability and resilience, just like the macro-ecosystems that humans rely upon for the supportive, provisioning and regulating ecosystem services. When natural habitats are degraded and environments polluted, ecological stability and resilience are often reduced, leading to a loss of trophic and genetic diversity, shifts in ecological communities, and sometimes to a state of ecological collapse $[25,26]$. The same concept applies to the holobiotic human ecosystem. This is supported by studies reporting positive health outcomes associated with higher microbial diversity such as reduced atopic sensitivity and favorable mental health $[27,28]$. Conversely, reduced microbial diversity has been linked to the onset of inflammatory diseases [29]. Further to metabolic benefits, it is thought that a diverse assemblage of microbiota in the gut, and on the skin, provides health benefits by outcompeting pathogenic microbiota [30]. This is analogous to native 
macroscopic vegetation resisting the potentially deleterious impacts of invasive species in, for example, a forest with high compositional and structural diversity [31].

Extending this argument to a clinical health perspective raises an important objective of microbiome research; that is, to gain a greater understanding of the role of microorganisms in the functioning of the human body. The microbiome is thought to influence various mammalian biotic systems and processes, from appetite and circadian rhythm, to emotional responses and immune regulation [32-35]. Researchers are discovering complex systems within the human body are partially, if not predominantly, influenced by microbial inhabitants. For example, the gut-brain axis is an area of research currently in the spotlight for this very reason. Researchers now believe that a bidirectional communication network exists between the central and enteric nervous systems and the microbiome within the human gut - that is, human-inhabiting microbiota are communicating with the brain and vice versa $[36,37]$.

A number of radical questions are now being asked, such as: can microbes influence the way we think, and even the dietary choices we make? This notion runs conceptually parallel to the central theorem of the extended phenotype, posited by Dawkins:

"An animal's behaviour tends to maximize the survival of the genes 'for' that behaviour, whether or not those genes happen to be in the body of the particular animal performing it". [38] (p. 13)

\section{Dysbiosis-'Life in Distress'}

With a growing understanding of microbial ecology and nature's complexity, it should be of no surprise that many aspects of human health are now considered to be inextricably linked to processes involving our microbiome. Conversely, several aspects of human ill-health are often a result of an unhealthy balance and reduced diversity of microbiota within and upon the human body $[39,40]$. This is also known as dysbiosis or 'life in distress' [41]. From a human health perspective, it is important to recognize that there is inter-individual variation in optimal microbial community structure and composition. Diversity of microbial communities is likely to play a major role in health as substantial functional redundancy exists amongst taxonomically distinct microbiota; that is, the microbial constituents of these open ecosystems can share similar functional roles [42]. In accordance with the redundancy hypothesis, this enables asynchronous responses during perturbation or disturbance, which helps to maintain system stability [43].

Dysbiosis exists on various levels, and within different realms-within our bodies, and within the wider environment, and it is the environment and not our genes, that has recently been shown to be the key driver of microbiome composition and health [44]. This notion is also supported by the 'old friends hypothesis', a refinement of the hygiene hypothesis, which proposes that in recent times, humans (particularly in so-called 'industrial' societies) have been exposed to a reduced number of immunoregulatory microorganisms from various sources, such as biodiverse environments and our diet (including breastfeeding), and that these microbes have co-evolved with the human immune system for millennia $[45,46]$. Indeed, it is the downfall of this relationship that has probably made a significant contribution to the etiopathogenesis of noncommunicable diseases such as asthma and inflammatory bowel disease $[47,48]$.

\section{Microbiome Rewilding and Planetary Health}

Humans are spending less time in natural environments, particularly those with higher levels of biodiversity, and less time interacting with natural organisms-physically, psychologically and biochemically. This reduction in exposure to biodiversity has been linked to a wide range of health conditions, from the inflammatory diseases mentioned previously, to depression and anxiety $[49,50]$. One proposed solution to the health implications of reduced biodiversity exposure is microbiome rewilding [51].

The microbiome rewilding hypothesis posits that ecological restoration of urban green spaces can rewild urban spaces to a health-promoting habitat, where urban lifestyles can become interconnected 
with greater biodiversity [51]. Importantly, this type of interconnected lifestyle comes with a rich exposure to diverse microbiota and the associated health benefits common to traditional and agricultural communities [52]. Urban residents surrounded by more green space tend to be healthier, regardless of socioeconomic status [53]. As previously discussed, diverse microbiota are fundamental to good human health. Microbiota are involved in the health of most holobionts, including many animals and plants. It is from this co-dependency platform that microbiome rewilding is premised, and we will now explore that further.

Coevolution has produced host species-specific assembly mechanisms for core microbiota $[54,55]$ that perform various functions, such as mycorrhizal nutrient acquisition in plants and short-chain fatty acid production in mammals. Therefore, a biodiverse community should produce a microbially diverse environment. However, within each holobiont, a portion of the microbiota remains plastic. This plasticity means that microbiota of individual holobionts are to some degree moderated by environmental microbiota. This is evidenced by captive Jamaican fruit bats having skin microbiota more similar to their co-habiting Seba's short-tailed bats than to another population of captive Jamaican fruit bats [56]. Additionally, leaf-surface microbiota of plants have been experimentally shown to be strongly influenced by the richness and functional diversity of their plant community [57]. Furthermore, Finnish children from rural areas have a skin microbiota distinct to those from urban areas [58]. Therefore, if the urban habitat is more biodiverse then people living there and using the space should have more diverse microbiota, resulting in better functioning immune systems. However, microbiome rewilding as a health care intervention must be used in concert with healthy dietary and other lifestyle choices that promote diverse symbiotic microbiota and proper immune function.

Microbiome rewilding of human habitats may have important co-benefits for planetary health. Co-benefits include biodiversity conservation [59], urban agriculture benefits [60], and lower crime rates with increased community cohesiveness [61]. Further, people who are more exposed to natural environments show greater concern for environmental issues beyond the noncommunicable disease epidemic discussed here [62]. Such issues can include deforestation, industrial agriculture, single-use plastics, and climate change. These are among the most pressing issues our species has ever faced. These issues require collective consciousness and action at all scales to shape a positive, healthy future for human life on Earth.

\section{Microbiome-Inspired Green Infrastructure (MIGI)}

Building on the microbiome rewilding hypothesis, a term that has recently been proposed is 'microbiome-inspired green infrastructure' (MIGI) [63]. MIGI is a collective term for living, multifunctional green spaces that are designed and manipulated to generate health-inducing microbial interactions (Figure 1). This is based on the premise that biodiverse microbial habitats can be 'restored' as per the microbiome rewilding hypothesis.

The 'inspired' part of MIGI implies a significant design element. Design considerations include multifunctional roles for social activities and ecosystem services, and both dynamic and static spatial factors within urban settings. For example, understanding how pollution, area, proximity, aspect, and urban physical features such as buildings, roads, and other structures, influence the dynamics of MIGI will be essential. It is also important to extend beyond the domains of localized mechanisms and impacts, and to determine whether interconnected systems of MIGI can "improve the microbial network fragility of larger urban areas such as 'megacities', which have been linked to human diseases" $[63,64]$. Furthermore, as a prospective ecological and public health intervention, MIGI should be designed to maximize ecological justice and reduce health inequalities; for example, by ensuring equity of access where public land is concerned. Gaining a detailed understanding of the dynamics between MIGI availability vs. optimal exposure to, and interaction with, health-inducing microbial community assemblages, will play a key role throughout the MIGI design, implementation and monitoring process. 


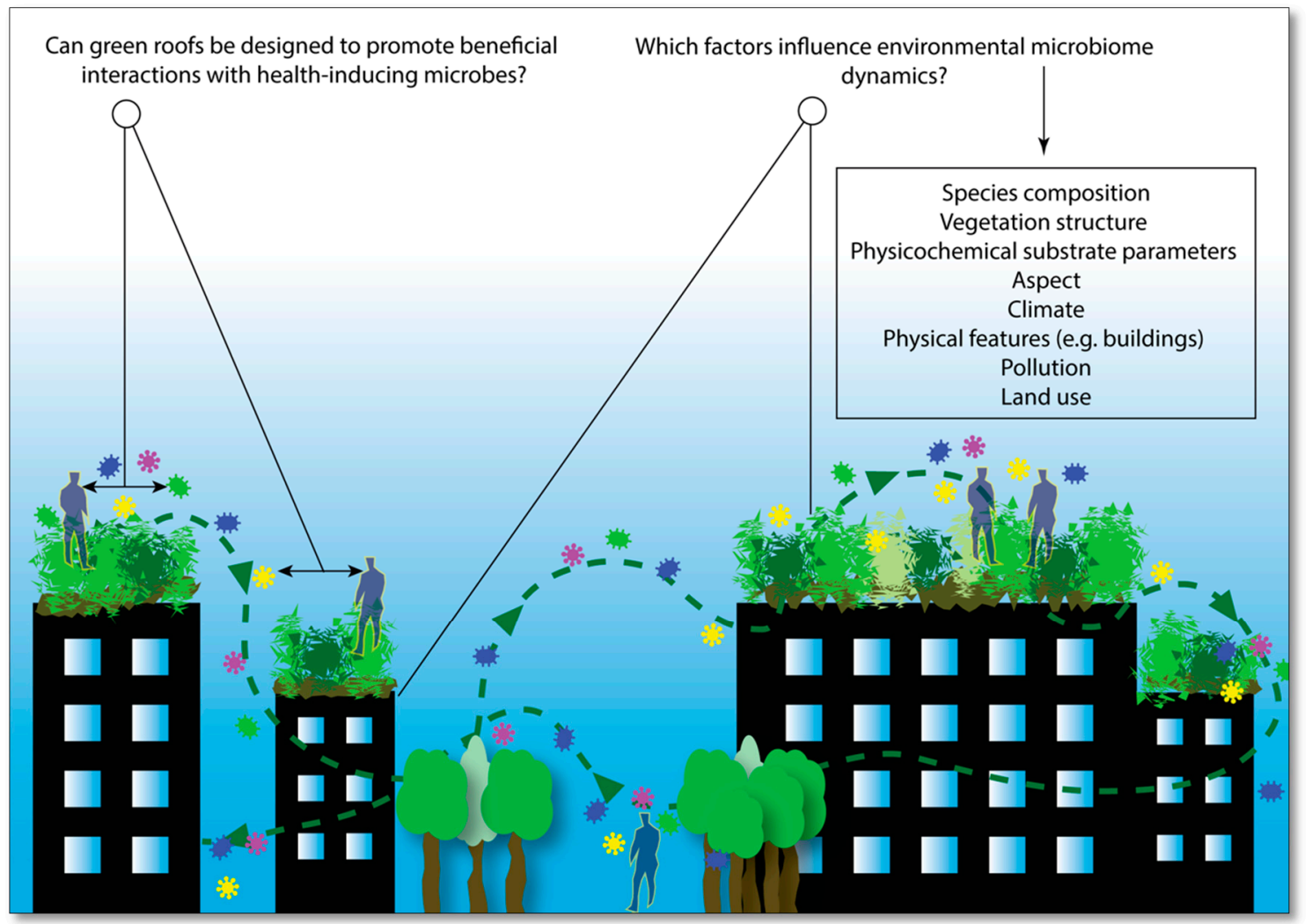

Figure 1. Could green roofs be designed and manipulated to promote beneficial interactions with health-inducing microbial assemblages, i.e., 'old friends'? (created by the author, from Reference [63]).

'Inspired' also implies a detailed understanding of environmental microbiome dynamics--the functional relationships between microbiota and vegetation, the spatiotemporal and compositional dynamics, and the mechanisms and pathways that facilitate human-microbial exchange and associated benefits. These factors are still poorly understood and a concerted effort to establish research and communication methods is needed to rapidly progress our understanding of what is known as "microbial dark matter" [65] — the microbial presence, abundance, composition and functionality in the environment. This continual generation of knowledge will allow for informed applications of MIGI, optimized to benefit humans and the environment.

\subsection{Microbiome-Inspired Green Infrastructure-Foraging}

From a societal evolution perspective, the human microbiome has gradually decreased in community diversity as human populations have passed along the following trajectory:

Foraging $\rightarrow$ Rural farming $\rightarrow$ Urban industrial lifestyles [66].

A number of studies point to the link between high human microbial diversity and the foraging lifestyle [67-69]. Therefore, it is envisaged that the application of MIGI will include foraging-friendly green spaces (Figure 2). This will require a collaborative effort between landscape architects, ecologists, agriculturalists and urban planners to create innovative food planting schemes that replicate (partially, at least) and promote foraging behavior. The ultimate aim of this strategy is to enhance human-environment microbial interactions and increase the diversity of microbiota residing in and on the human body. Foraging also augments the multisensorial experience (i.e., touch, sight, smell), which brings its own intrinsic advantages as nature-derived health benefits arrive through a variety of senses $[70,71]$. 


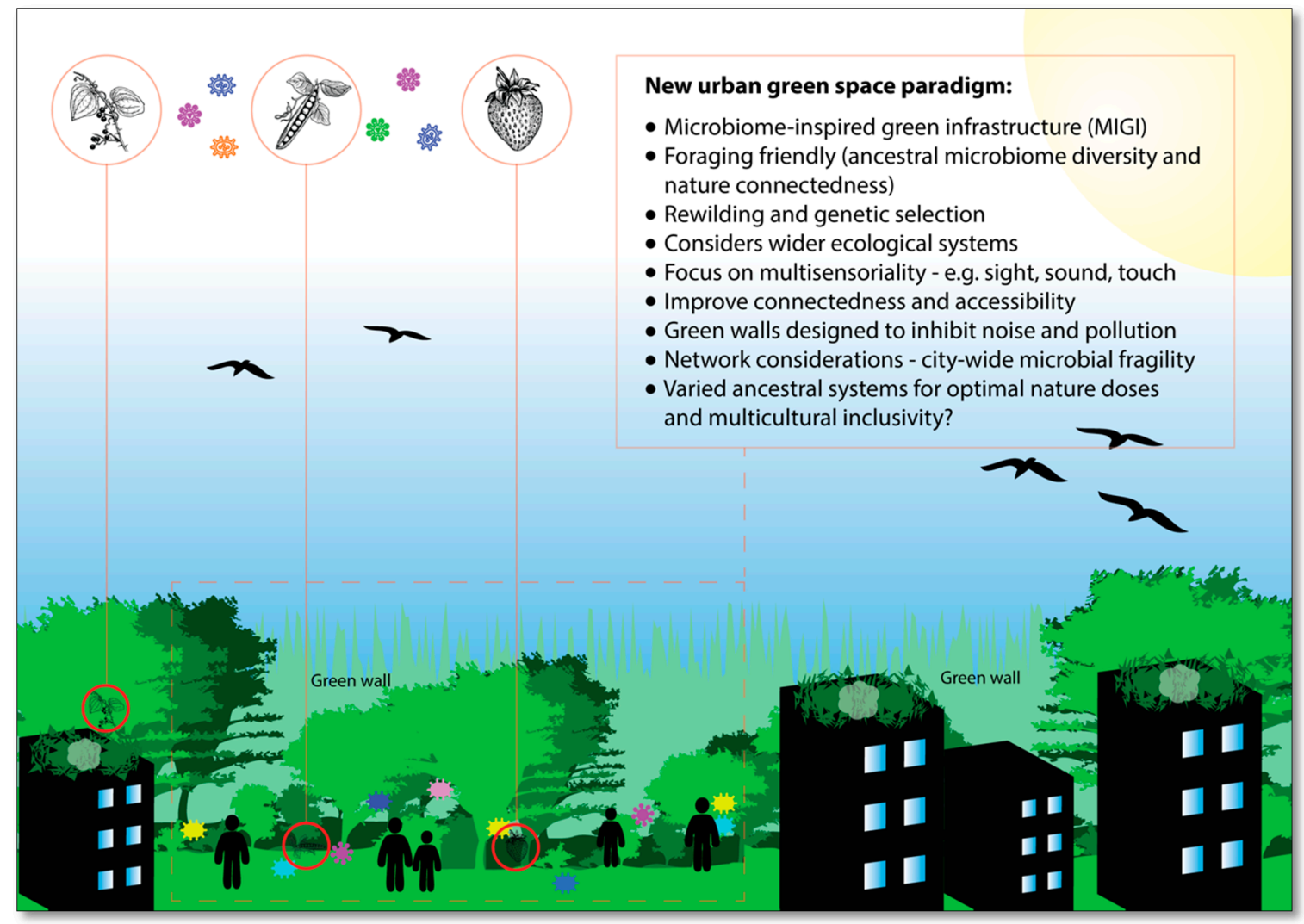

Figure 2. A vision for the future: microbiome-inspired green infrastructure (MIGI) and multisensorial, multiculturally inclusive, and foraging-friendly green spaces (created by the author).

Foraging is already ubiquitous across the globe; however, it is often prohibited or discouraged in urban areas [72]. Formal strategies to draw together the benefits of foraging are needed, and with further research, the potential benefits of health-inducing microbial exchange will likely strengthen this approach. Urban foraging manifests in a variety of forms from harvesting the fruit of street trees to participating in community gardening. It would be prudent for researchers to investigate the differences (in terms of microbial exchange and health outcomes) between these foraging methods, as this would help inform the design and management of MIGI in the future. There are also concerns that need to be addressed, such as urban pollutants and perceived 'mess' from fallen fruits [73]. The former calls for innovation in planting design plus plant protection and selection, and broader strategies to reduce pollution. The latter would benefit from a shift in perception of the value of these food sources, mobilized perhaps through community-centric groups such as the Grow Sheffield's Abundance Project [74] — an initiative that promotes the harvesting of food plants across the city and redistributes the 'products' to food banks and local communities.

Urban foraging schemes may well need to adapt to the intensively dynamic socio-ecological complexities of urbanization; for example, changing ownership of land, building development, and changes to infrastructure. However, recent innovation is helping to address this issue. For example, mobile allotments, such as those created by the arts and environment project Avant Gardening [75] can be installed on vacant lots to provide communities with a foraging hub, and easily moved if the land status changes. It is also important to note that in addition to the potential of health-inducing microbial exchange, community gardening can generate other health and wellbeing benefits (e.g., through physical exercise, psychological restoration and nature connectedness) and enhance social cohesion [76,77].

These potentially health-inducing interactions with environmental microbiota may also be enhanced via physical engagement with the substrate that supports the food plants. Cutting-edge 
research by Lowry on the soil microorganism Mycobacterium vaccae has shown that when injected in mice, this non-pathogenic bacterium can activate 5-hydroxytryptamine (serotonin) in the prefrontal cortex, helping to regulate coping responses to "uncontrollable stress" [78]. The potential health benefits of $M$. vaccae do not end here; the inoculation of this microorganism has also been shown to protect against neuroinflammation and cognitive dysfunction, and to have immune boosting effects $[79,80]$. This is just the story for a single species of bacterium that can influence cognition, behavior and immunity. This speaks volumes for the potential of the other estimated $\sim 1 \times 10^{5}$ genera of bacteria and archaea on the planet, of which only $\sim 11,000$ species have been classified [81]. The possibilities here for MIGI are multitudinous-Are there certain natural habitats that can optimize interactions with health-inducing microbiota? Can we isolate different microbial species and manipulate communities to enhance these interactions? The research is in its infancy, but the potential is immense.

\subsection{Microbiome-Inspired Green Infrastructure-Green Barriers}

Natural green walls such as hedgerows with trees could also be designed as part of MIGI to reduce noise pollution, improve the multisensorial experience, and reduce pollution in green spaces by trapping particulate matter $[82,83]$. However, these features would also need to be scrupulously curated to allow optimal wind dispersal to prevent localized concentration of pollution [84]. Additional research is needed to understand the impact of green walls on these mechanisms, but green barrier designs could potentially help shield humans and microbial communities in green spaces from industrial pollutants and contribute to the reduction in respiratory illnesses [84]. It is worth noting that despite the benefits, the potential of these features as allergen producers and disease vector habitats should also be considered as part of an assessment of suitability.

\subsection{Microbiome-Inspired Green Infrastructure—Cultural and Ancestral Microbiomes}

Due to increasing cultural diversity of western towns and cities [85], it is essential to emphasize the importance of inclusivity in urban green space designs. It then follows that creating inclusive environments should also be a key consideration for MIGI. Further research into the potential inclusion of inter-ethnic ancestral environments in urban areas to optimize microbial interactions and immune regulation could be important for the development of effective MIGI. Evidence points to ancestry-associated differences in human immune responses, and populations vary in their susceptibility to diseases [86]. Furthermore, human microbiome composition varies significantly across different ethnic groups $[68,87,88]$, which has only been partially explained by factors such as sociodemographic dynamics and diet $[89,90]$.

From an immune development perspective, it is possible that specific inter-ethnic interactions with ancestral microbial communities in natural environments are important to the health of these populations. It is also possible that functional redundancy between microbiota and widespread human genetic admixture may neutralize the effectiveness of this theory; however, it has been pointed out that there is evidence to question the "universality of microbiome-based therapeutic strategies" based on ethnic and geographical variation [66]. Ancestry aside, there are also important cultural and generational considerations for MIGI here. For example, in many countries, children are spending less time outdoors and interacting with nature [91]. This is attributed to a range of factors such as changes in cultural practices and green space accessibility [91,92]. MIGI could also be designed with cultural changes in mind; for example, establishing MIGI in areas where children do spend time, or integrating MIGI strategies with cultural trends. An example of the former could be the establishment of MIGI in and around skate parks, and an example of the latter could be to work with developers of location-based augmented reality games such as Pokémon GO to promote spending time in areas where MIGI has already been established or could be established in the future. After all, this kind of technology is unlikely to disappear, and whilst strong arguments can be made to proactively reduce 'screen time' and promote contact with nature, this technology-human-nature interface has 
also been suggested to provide new links between humans and green space and encouraging physical activity [93]. More research into the potential salutogenic effects of 'nature exposure' whilst using this technology is essential.

The prospect of including different cultural and ethnic ancestral environments to promote health-inducing microbial interactions and multicultural inclusivity is a tantalizing one. However, a significant amount of additional research is needed to further understand the relationships between culture, ancestral environments, microbiota and inter-ethnic health. It will also be essential to consider the potential impacts of including novel environmental features in native ecosystems. A network of closed MIGI systems (i.e., cultural and ancestral biomes) could be an option in the future.

\subsection{Microbiome-Inspired Green Infrastructure—Plant Microbiome Selection and Engineering}

As with humans, plants and their microbiomes form a holobiont, and the interplay between the plant host and its co-evolving microbial assemblages has a substantial role in maintaining the health of these functional ecological units [94]. Microbial diversity is a key driving factor in maintaining favorable plant health [94,95]. Indeed, individual plant genotypes can show distinct microbial diversity, which indicates that some plants have the ability to cultivate a beneficial microbiome and this process may be under natural selection [96]. Therefore, strategies to enhance microbial diversity to benefit human health also have the potential to generate important co-benefits for plants, with cascading benefits to the wider ecosystem. This further highlights the importance of the interconnectedness of life. Understanding how plant community composition, independent of diversity, affects the microbiome is also an important factor, particularly in 'designed' urban environments. For example, specific pairwise and synergistic interactions in plant communities can be selected to influence the soil microbiome structure and pathogen suppression [97]. Plant microbiomes can also be genetically selected to enhance fitness [98]; i.e., plant growth promotion, plant health and abiotic stress tolerance [99,100]. Genotype-dependent associations between plants and the microbiome could be used to target and establish optimal MIGI dynamics, and careful selection processes may play important roles in the design, implementation and effectiveness of MIGI in the future.

\section{Nature Connections and Green Prescriptions}

Restoring biodiverse urban habitats and designing multifunctional green infrastructure to enhance microbial interactions has the potential to contribute towards planetary health in a number of ways. For example, mounting evidence supports a range of direct health benefits associated with spending time in nature, and there is the obvious enhancement of natural habitats and the contributions this makes towards biodiversity conservation, ecological stability and network connectivity. However, there is also potential to enhance pro-environmental behaviors and environmental stewardship, not only by providing opportunities to promote ecological education, but by providing additional opportunities to access and connect with natural environments. Indeed, it is difficult to overstate the importance of reinstating the intrinsic health-inducing connections between humans and nature; connections that are damaged when we fail to acknowledge the importance of reciprocity in the human-nature relationship [101].

From a psychological perspective, 'nature connectedness' is a multidimensional concept that involves one's "affective, cognitive and physical relationship with the natural world" [102]. Nature connectedness is an important indicator of pro-environmental behaviors and is associated with psychological wellbeing [103]. Furthermore, engagement in nature-based activities can facilitate changes in nature connectedness, and positive impacts derived from exposure to nature could be mediated by an increase in nature connectedness resulting from this very exposure [103,104].

Nature-based health interventions, also known as 'green prescriptions', are an emerging integrative approach, aimed at addressing noncommunicable diseases and social isolation [63]. Green prescriptions work on the premise that exposure to, and interactions with, natural environments bring variable degrees of health benefits, which can be prescribed and monitored over time $[105,106]$. As 
with microbiome rewilding and ecological restoration, green prescribing has the potential to deliver important co-benefits to humans and the environment. In fact, green prescribing activities can include biodiversity conservation, and as such, patients could potentially help to conserve and restore habitats and rewild the microbiome, whilst simultaneously benefiting from a variety of health-inducing interactions. More research is needed to understand what type of exposure to nature is optimal, and also how much, when and for whom [107]. However, for a near-future urban green paradigm that focuses on promoting ecological justice, multicultural inclusivity and widespread foraging-friendly green spaces, green prescribing can play a key role in bridging these objectives and sustaining lifestyles based on underlying holistic principles.

\section{Conclusions}

The human body is a holobiotic organism; a walking ecosystem that intertwines the macro and micro ecosystems in the Earth's biosphere. As Prescott of inVIVO Planetary Health has said "natural laws of interdependence, mutualism, and interconnectivity underpin life in all forms"-including the seen and unseen [108].

Enhancing the diversity of both the macro and microbiological constituents of the natural world, whilst working towards a greater understanding of microbial functions and dynamics within our bodies and the wider environment, brings a considerable and mutually-advantageous asset to the planetary health paradigm. Furthermore, promoting the advantages of connecting with nature for physical and psychological health and wellbeing (mediated by strategies such as green prescribing, ecological restoration and rewilding, and innovative microbiome-inspired green infrastructure) can only improve this position. This can be enhanced further by a number of potential socioecological benefits such as environmental stewardship, social cohesion and multicultural inclusivity. We believe there are countless possibilities for microbiome-inspired green infrastructure, particular if researchers and those in practice work collaboratively across disciplines to progress this concept. There is an opportunity for a concerted effort to explore the potential of human-environmental microbial exchange and associated health benefits, whilst developing important co-beneficial strategies to maximize the impact of these on humans and the environment.

As our species, or our collective holobionts, moves forward in the Anthropocene, perhaps an epoch that we could aspire to is the 'Symbiocene'. This is a term first coined by Albrecht, the Australian 'eco-philosopher' based on a need to take a more holistic, symbiotic and ecological approach to the way we live [109]. The prospective strategies mentioned in our paper are aimed at addressing the global challenge of halting and reversing dysbiosis in all its manifestations. Collectively, it is hoped these strategies, along with taking an ecological view of the human body, will contribute towards improving personal and planetary health.

Author Contributions: Conceptualization of MIGI, J.M.R.; conceptualization of microbiome rewilding hypothesis, J.G.M. and M.F.B.; investigation, J.M.R., J.G.M. and M.F.B.; writing—original draft preparation, J.M.R., J.G.M. and M.F.B.; writing—review and editing, J.M.R., J.G.M. and M.F.B.; visualization, J.M.R.

Funding: J.M.R. is undertaking a PhD through the White Rose Doctoral Training Partnership (WRDTP), funded by the Economic and Social Research Council (ESRC). M.F.B. is supported by the Australian Research Council and Australian Smart Cities Consortium.

Conflicts of Interest: The authors declare no conflicts of interest.

\section{References}

1. Van de Guchte, M.; Blottière, H.M.; Doré, J. Humans as holobionts: Implications for prevention and therapy. Microbiome 2018, 6, 81. [CrossRef] [PubMed]

2. Dheilly, N.M. Holobiont-Holobiont interactions: Redefining host-parasite interactions. PLoS Pathog. 2014, 10, e1004093. [CrossRef] [PubMed]

3. Pronin, E. How we see ourselves and how we see others. Science 2008, 320, 1177-1180. [CrossRef] [PubMed] 
4. Smith, V.H.; Rubinstein, R.J.; Park, S.; Kelly, L.; Klepac-Ceraj, V. Microbiology and ecology are vitally important to premedical curricula. Evol. Med. Public Health 2015, 2015, 179-192. [CrossRef] [PubMed]

5. Prescott, S.L.; Logan, A.C. Down to earth: Planetary health and biophilosophy in the symbiocene epoch. Challenges 2017, 8, 19. [CrossRef]

6. Flandroy, L.; Poutahidis, T.; Berg, G.; Clarke, G.; Dao, M.C.; Decaestecker, E.; Furman, E.; Haahtela, T.; Massart, S.; Plovier, H.; et al. The impact of human activities and lifestyles on the interlinked microbiota and health of humans and of ecosystems. Sci. Total Environ. 2018, 627, 1018-1038. [CrossRef] [PubMed]

7. Pongsiri, M.J.; Gatzweiler, F.W.; Bassi, A.M.; Haines, A.; Demassieux, F. The need for a systems approach to planetary health. Lancet Planet. Health 2017, 1, e257-e259. [CrossRef]

8. Seltenrich, N. Down to Earth: The Emerging Field of Planetary Health. Environ. Health Perspect. 2018, 126, 072001. [CrossRef] [PubMed]

9. Tonello, L.; Gashi, B.; Scuotto, A.; Capello, G.; Cocchi, M.; Gabrielli, F.; Tuszynski, J.A. The gastrointestinal-brain axis in humans as an evolutionary advance of the root-leaf axis in plants: A hypothesis linking quantum effects of light on serotonin and auxin. J. Integr. Neurosci. 2018, 17, 227-237. [CrossRef]

10. Daubin, V.; Szöllősi, G.J. Horizontal gene transfer and the history of life. Cold Spring Harbor. Perspect. Biol. 2016, 8, a018036.

11. Quammen, D. The Tangled Tree: A Radical New History of Life; Simon and Schuster, Inc.: New York, NY, USA, 2018.

12. Sorriento, D.; Pascale, A.V.; Finelli, R.; Carillo, A.L.; Annunziata, R.; Trimarco, B.; Iaccarino, G. Targeting mitochondria as therapeutic strategy for metabolic disorders. Sci. World J. 2014, 2014, 604685. [CrossRef] [PubMed]

13. Gray, M.W. Mitochondrial evolution. Cold Spring Harbor. Perspect. Biol. 2012, 4, a011403.

14. Knight, R. Integrated Approaches to Analyze Big Data in the Perinatal/Neonatal Space. Breastfeed. Med. 2018, 13, S-5-S-6. [CrossRef] [PubMed]

15. Qin, J.; Li, R.; Raes, J.; Arumugam, M.; Burgdorf, K.S.; Manichanh, C.; Nielsen, T.; Pons, N.; Levenez, F.; Yamada, T.; et al. A human gut microbial gene catalogue established by metagenomic sequencing. Nature 2010, 464, 59-65. [CrossRef] [PubMed]

16. Zhang, X.; Liu, S.; Cui, H.; Chen, T. Reading the Underlying Information from Massive Metagenomic Sequencing Data. Proc. IEEE 2017, 105, 459-473. [CrossRef]

17. Fierer, N.; Hamady, M.; Lauber, C.L.; Knight, R. The influence of sex, handedness.; washing on the diversity of hand surface bacteria. Proc. Natl. Acad. Sci. USA 2008, 105, 17994-17999. [CrossRef] [PubMed]

18. Jordán, F.; Lauria, M.; Scotti, M.; Nguyen, T.P.; Praveen, P.; Morine, M.; Priami, C. Diversity of key players in the microbial ecosystems of the human body. Sci. Rep. 2015, 5, 15920. [CrossRef] [PubMed]

19. Mirzaei, M.K.; Maurice, C.F. The Mammalian Gut as a Matchmaker. Cell Host Microbe 2017, 22, $726-727$. [CrossRef] [PubMed]

20. Shreiner, A.B.; Kao, J.Y.; Young, V.B. The gut microbiome in health and in disease. Curr. Opin. Gastroenterol. 2015, 31, 69-75. [CrossRef] [PubMed]

21. Mazidi, M.; Rezaie, P.; Kengne, A.P.; Mobarhan, M.G.; Ferns, G.A. Gut microbiome and metabolic syndrome. Diabetes \& Metabolic Syndrome. Clin. Res. Rev. 2016, 10, S150-S157.

22. Sivaprakasam, S.; Prasad, P.D.; Singh, N. Benefits of short-chain fatty acids and their receptors in inflammation and carcinogenesis. Pharmacol. Ther. 2016, 164, 144-151. [CrossRef] [PubMed]

23. Li, X.; Shimizu, Y.; Kimura, I. Gut microbial metabolite short-chain fatty acids and obesity. Biosci. Microbiota Food Health 2017, 36, 135-140. [CrossRef] [PubMed]

24. TEDx. Feed Your Microbes-Nurture Your Mind; Online Video. 2017. Available online: https://www. youtube.com/watch?v=vKxomLM7SVc (accessed on 20 August 2018).

25. Dobson, A.; Lodge, D.; Alder, J.; Cumming, G.S.; Keymer, J.; McGlade, J.; Mooney, H.; Rusak, J.A.; Sala, O.; Wolters, V.; et al. Habitat loss, trophic collapse, and the decline of ecosystem services. Ecology 2006, 87, 1915-1924. [CrossRef]

26. Mahoney, P.C.; Bishop, M.J. Assessing risk of estuarine ecosystem collapse. Ocean Coast. Manag. 2017, 140, 46-58. [CrossRef]

27. Ruokolainen, L.; von Hertzen, L.; Fyhrquist, N.; Laatikainen, T.; Lehtomäki, J.; Auvinen, P.; Karvonen, A.M.; Hyvärinen, A.; Tillmann, V.; Niemelä, O.; et al. Green areas around homes reduce atopic sensitisation in children. Allergy 2015, 70, 196-202. [CrossRef] [PubMed] 
28. Clapp, M.; Aurora, N.; Herrera, L.; Bhatia, M.; Wilen, E.; Wakefield, S. Gut microbiota's effect on mental health: The gut-brain axis. Clin. Pract. 2017, 7, 987. [CrossRef] [PubMed]

29. Huttenhower, C.; Gevers, D.; Knight, R.; Abubucker, S.; Badger, J.H.; Chinwalla, A.T.; Creasy, H.H.; Earl, A.M.; FitzGerald, M.G.; Fulton, R.S.; et al. Structure, function and diversity of the healthy human microbiome. Nature 2012, 486, 207-214.

30. Ferreyra, J.A.; Ng, K.M.; Sonnenburg, J.L. The enteric two-step: Nutritional strategies of bacterial pathogens within the gut. Cell. Microbiol. 2014, 16, 993-1003. [CrossRef] [PubMed]

31. Guyot, V.; Castagneyrol, B.; Vialatte, A.; Deconchat, M.; Selvi, F.; Bussotti, F.; Jactel, H. Tree diversity limits the impact of an invasive forest pest. PLoS ONE 2015, 10, e0136469. [CrossRef] [PubMed]

32. Alcock, J.; Maley, C.C.; Aktipis, C.A. Is eating behavior manipulated by the gastrointestinal microbiota? Evolutionary pressures and potential mechanisms. Bioessays 2014, 36, 940-949. [CrossRef] [PubMed]

33. Thaiss, C.A.; Levy, M.; Korem, T.; Dohnalová, L.; Shapiro, H.; Jaitin, D.A.; David, E.; Winter, D.R.; Gury-BenAri, M.; Tatirovsky, E.; et al. Microbiota diurnal rhythmicity programs host transcriptome oscillations. Cell 2016, 167, 1495-1510. [CrossRef] [PubMed]

34. Bagga, D.; Reichert, J.L.; Koschutnig, K.; Aigner, C.S.; Holzer, P.; Koskinen, K.; Moissl-Eichinger, C.; Schöpf, V. Probiotics drive gut microbiome triggering emotional brain signatures. Gut Microbes 2018, 1-11. [CrossRef] [PubMed]

35. Chhabra, P.; Spano, A.J.; Bowers, D.; Ren, T.; Moore, D.J.; Timko, M.P.; Wu, M.; Brayman, K.L. Evidence for the Role of the Cecal Microbiome in Maintenance of Immune Regulation and Homeostasis. Ann. Surg. 2018, 268, 541-549. [CrossRef] [PubMed]

36. Foster, J.A.; Rinaman, L.; Cryan, J.F. Stress \& the gut-brain axis: Regulation by the microbiome. Neurobiol. Stress 2017, 7, 124-136. [PubMed]

37. Bonaz, B.; Bazin, T.; Pellissier, S. The Vagus Nerve at the Interface of the Microbiota-Gut-Brain Axis. Front. Neurosci. 2018, 12, 49. [CrossRef] [PubMed]

38. Dawkins, R. The Extended Phenotype; Oxford University Press: Oxford, UK, 1989; p. 13. ISBN 0-19-288051-9.

39. Carding, S.; Verbeke, K.; Vipond, D.T.; Corfe, B.M.; Owen, L.J. Dysbiosis of the gut microbiota in disease. Microb. Ecol. Health Dis. 2015, 26, 26191. [CrossRef] [PubMed]

40. Ohri, N.; Gerich, M.E.; Fennimore, B.P.; Ir, D.; Robertson, C.E.; Regener, E.; Caplan, L.; Wagner, B.D.; Frank, D.N.; Kuhn, K. Bacterial Dysbiosis Associates with Functional Intraepithelial Lymphocyte Changes in Inflammatory Bowel Disease and Spondyloarthritis. J. Immunol. 2017, 198, 46-55.

41. Logan, A.C. Dysbiotic drift: Mental health, environmental grey space.; microbiota. J. Physiol. Anthropol. 2015, 7, 23. [CrossRef] [PubMed]

42. Louca, S.; Polz, M.F.; Mazel, F.; Albright, M.B.; Huber, J.A.; O’Connor, M.I.; Ackermann, M.; Hahn, A.S.; Srivastava, D.S.; Crowe, S.A.; et al. Function and functional redundancy in microbial systems. Nat. Ecol. Evol. 2018, 2, 936-943. [CrossRef] [PubMed]

43. Kang, S.; Ma, W.; Li, F.Y.; Zhang, Q.; Niu, J.; Ding, Y.; Han, F.; Sun, X. Functional redundancy instead of species redundancy determines community stability in a typical steppe of Inner Mongolia. PLoS ONE 2015, 10, e0145605. [CrossRef] [PubMed]

44. Rothschild, D.; Weissbrod, O.; Barkan, E.; Kurilshikov, A.; Korem, T.; Zeevi, D.; Costea, P.I.; Godneva, A.; Kalka, I.N.; Bar, N.; et al. Environment dominates over host genetics in shaping human gut microbiota. Nature 2018, 555, 210-215. [CrossRef] [PubMed]

45. Rook, G.A.; Brunet, L.R. Old friends for breakfast. Clin. Exp. Allergy 2005, 35, 841-842. [CrossRef] [PubMed]

46. Rook, G.A.W.; Brunet, L.R. Microbes, immunoregulation, and the gut. Gut 2005, 54, 317-320. [CrossRef] [PubMed]

47. Haahtela, T.; Holgate, S.; Pawankar, R.; Akdis, C.A.; Benjaponpitak, S.; Caraballo, L.; Demain, J.; Portnoy, J.; von Hertzen, L. The biodiversity hypothesis and allergic disease: World allergy organization position statement. World Allergy Organ. J. 2013, 6, 1. [CrossRef] [PubMed]

48. Bloomfield, S.F.; Rook, G.A.; Scott, E.A.; Shanahan, F.; Stanwell-Smith, R.; Turner, P. Time to abandon the hygiene hypothesis: New perspectives on allergic disease, the human microbiome, infectious disease prevention and the role of targeted hygiene. Perspect. Public Health 2016, 136, 213-224. [CrossRef] [PubMed]

49. Pearson, D.G.; Craig, T. The great outdoors? Exploring the mental health benefits of natural environments. Front. Psychol. 2014, 5, 1178. [CrossRef] [PubMed] 
50. Snell, T.L.; Lam, J.C.; Lau, W.W.Y.; Lee, I.; Maloney, E.M.; Mulholland, N.; Wilson, L.; Wynne, L.J. Contact with nature in childhood and adult depression. Child. Youth Environ. 2016, 26, 111-124. [CrossRef]

51. Mills, J.G.; Weinstein, P.; Gellie, N.J.C.; Weyrich, L.S.; Lowe, A.J.; Breed, M.F. Urban habitat restoration provides a human health benefit through microbiome rewilding: The Microbiome Rewilding Hypothesis. Restor. Ecol. 2017, 25, 866-872. [CrossRef]

52. Stein, M.M.; Hrusch, C.L.; Gozdz, J.; Igartua, C.; Pivniouk, V.; Murray, S.E. Innate immunity and asthma risk in Amish and Hutterite farm children. N. Engl. J. Med. 2016, 375, 411-421. [CrossRef] [PubMed]

53. Brindley, P.; Jorgensen, A.; Maheswaran, R. Domestic gardens and self-reported health: A national population study. Int. J. Health Geogr. 2018, 17, 31. [CrossRef] [PubMed]

54. Lundberg, D.S.; Lebeis, S.L.; Paredes, S.H.; Yourstone, S.; Gehring, J.; Malfatti, S.; Tremblay, J.; Engelbrektson, A.; Kunin, V.; Del Rio, T.G.; et al. Defining the core Arabidopsis thaliana root microbiome. Nature 2012, 488, 86-90. [CrossRef] [PubMed]

55. Turnbaugh, P.J.; Ley, R.E.; Hamady, M.; Fraser-Liggett, C.M.; Knight, R.; Gordon, J.I. The human microbiome project. Nature 2007, 449, 804-810. [CrossRef] [PubMed]

56. Lemieux-Labonté, V.; Tromas, N.; Shapiro, B.J.; Lapointe, F.-J. Environment and host species shape the skin microbiome of captive neotropical bats. Peer] 2016, 4, e2430. [CrossRef] [PubMed]

57. Laforest-Lapointe, I.; Paquette, A.; Messier, C.; Kembel, S.W. Leaf bacterial diversity mediates plant diversity and ecosystem function relationships. Nature 2017, 546, 145-147. [CrossRef] [PubMed]

58. Lehtimäki, J.; Karkman, A.; Laatikainen, T.; Paalanen, L.; Von Hertzen, L.; Haahtela, T.; Hanski, I.; Ruokolainen, L. Patterns in the skin microbiota differ in children and teenagers between rural and urban environments. Sci. Rep. 2017, 7, 45651. [CrossRef] [PubMed]

59. Goddard, M.A.; Dougill, A.J.; Benton, T.G. Scaling up from gardens: Biodiversity conservation in urban environments. Trends Ecol. Evol. 2010, 25, 90-98. [CrossRef] [PubMed]

60. Jansson, Å. Reaching for a sustainable, resilient urban future using the lens of ecosystem services. Ecol. Econ. 2013, 86, 285-291. [CrossRef]

61. Weinstein, N.; Balmford, A.; Dehaan, C.R.; Gladwell, V.; Bradbury, R.B.; Amano, T. Seeing community for the trees: The links among contact with natural environments, community cohesion.; crime. Bioscience 2015, 65, 1141-1153. [CrossRef]

62. Bögeholz, S. Nature experience and its importance for environmental knowledge, values and action: Recent German empirical contributions. Environ. Educ. Res. 2006, 12, 65-84. [CrossRef]

63. Robinson, J.M.; Jorgensen, A. Rekindling Old Friendships in New Landscapes: The Environment-Microbiome-Health Axis in the Realms of Landscape Research. People Nat. 2018. manuscript submitted.

64. Kim, H.J.; Kim, H.; Kim, J.J.; Myeong, N.R.; Kim, T.; Park, T.; Kim, E.; Choi, J.Y.; Lee, J.; An, S.; et al. Fragile skin microbiomes in megacities are assembled by a predominantly niche-based process. Sci. Adv. 2018, 4, e1701581. [CrossRef] [PubMed]

65. Rook, G.A. Regulation of the immune system by biodiversity from the natural environment: An ecosystem service essential to health. Proc. Natl. Acad. Sci. USA 2013, 110, 18360-18367. [CrossRef] [PubMed]

66. Gupta, V.K.; Paul, S.; Dutta, C. Geography, ethnicity or subsistence-specific variations in human microbiome composition and diversity. Front. Microbiol. 2017, 8, 1162. [CrossRef] [PubMed]

67. Nasidze, I.; Li, J.; Schroeder, R.; Creasey, J.L.; Li, M.; Stoneking, M. High diversity of the saliva microbiome in Batwa Pygmies. PLoS ONE 2011, 6, e23352. [CrossRef] [PubMed]

68. Schnorr, S.L.; Candela, M.; Rampelli, S.; Centanni, M.; Consolandi, C.; Basaglia, G.; Turroni, S.; Biagi, E.; Peano, C.; Severgnini, M.; et al. Gut microbiome of the Hadza hunter-gatherers. Nat. Commun. 2014, 5, 3654. [CrossRef] [PubMed]

69. Fragiadakis, G.K.; Smits, S.A.; Sonnenburg, E.D.; Van Treuren, W.; Reid, G.; Knight, R.; Manjurano, A.; Changalucha, J.; Dominguez-Bello, M.G.; Leach, J.; et al. Links between environment, diet, and the hunter-gatherer microbiome. bioRxiv 2018, 319673. [CrossRef] [PubMed]

70. Franco, L.S.; Shanahan, D.F.; Fuller, R.A. A review of the benefits of nature experiences: More than meets the eye. Int. J. Environ. Res. Public Health 2017, 14, 864. [CrossRef] [PubMed]

71. Van den Bosch, M.; Bird, W. Oxford Textbook of Nature and Public Health; Oxford University Press: Oxford, UK, 2018. 
72. Shackleton, C.M.; Hurley, P.T.; Dahlberg, A.C.; Emery, M.R.; Nagendra, H. Urban foraging: A ubiquitous human practice overlooked by urban planners, policy, and research. Sustainability 2017, 9, 1884. [CrossRef]

73. Kowalski, J.M.; Conway, T.M. Branching out: The inclusion of urban food trees in Canadian urban forest management plans. Urban For. Urban Green. 2018, in press. [CrossRef]

74. Grow Sheffield. 'The Abundance Project'. 2018. Available online: http://growsheffield.com/abundance/ (accessed on 2 November 2018).

75. Avant Gardening. Mobile Allotment. 2018. Available online: http://www.avantgardening.org/projects/ mobile.allotment (accessed on 2 November 2018).

76. Jang, H.S.; Gim, G.M.; Kim, K.J.; Jung, H.H. Psychological Healing Change of Workers Following After the Experiencing Indoor Garden Installation. J. Hum. Ecol. 2017, 20, 373-383. [CrossRef]

77. Veen, E.J.; Bock, B.B.; Van den Berg, W.; Visser, A.J.; Wiskerke, J.S. Community gardening and social cohesion: Different designs, different motivations. Local Environ. 2016, 21, 1271-1287. [CrossRef]

78. Lowry, C.A.; Hollis, J.H.; De Vries, A.; Pan, B.; Brunet, L.R.; Hunt, J.R.; Paton, J.F.; van Kampen, E.; Knight, D.M.; Evans, A.K.; et al. Identification of an immune-responsive mesolimbocortical serotonergic system: Potential role in regulation of emotional behavior. Neuroscience 2007, 146, 756-772. [CrossRef] [PubMed]

79. Fonken, L.K.; Frank, M.G.; D’Angelo, H.M.; Heinze, J.D.; Watkins, L.R.; Lowry, C.A.; Maier, S.F. Mycobacterium vaccae immunization protects aged rats from surgery-elicited neuroinflammation and cognitive dysfunction. Neurobiol. Aging 2018, 71, 105-114. [CrossRef] [PubMed]

80. Zheng, J.; Chen, L.; Liu, L.; Li, H.; Liu, B.; Zheng, D.; Liu, T.; Dong, J.; Sun, L.; Zhu, Y.; et al. Proteogenomic analysis and discovery of immune antigens in Mycobacterium vaccae. Mol. Cell. Proteom. 2017, 16, 1578-1590. [CrossRef] [PubMed]

81. Yarza, P.; Yilmaz, P.; Pruesse, E.; Glöckner, F.O.; Ludwig, W.; Schleifer, K.H.; Whitman, W.B.; Euzéby, J.; Amann, R.; Rosselló-Móra, R. Uniting the classification of cultured and uncultured bacteria and archaea using 16S rRNA gene sequences. Nat. Rev. Microbiol. 2014, 12, 635-645. [CrossRef] [PubMed]

82. Van Renterghem, T.; Hornikx, M.; Forssen, J.; Botteldooren, D. The potential of building envelope greening to achieve quietness. Build. Environ. 2013, 61, 34-44. [CrossRef]

83. Abhijith, K.V.; Kumar, P.; Gallagher, J.; McNabola, A.; Baldauf, R.; Pilla, F.; Broderick, B.; Di Sabatino, S.; Pulvirenti, B. Air pollution abatement performances of green infrastructure in open road and built-up street canyon environments-A review. Atmos. Environ. 2017, 162, 71-86. [CrossRef]

84. Soyiri, I.N.; Alcock, I. Green spaces could reduce asthma admissions. Lancet Respir. Med. 2018,6 , e1. [CrossRef]

85. Crul, M. Super-diversity vs. assimilation: How complex diversity in majority-minority cities challenges the assumptions of assimilation. J. Ethn. Migr. Stud. 2016, 42, 54-68. [CrossRef]

86. Nédélec, Y.; Sanz, J.; Baharian, G.; Szpiech, Z.A.; Pacis, A.; Dumaine, A.; Grenier, J.C.; Freiman, A.; Sams, A.J.; Hebert, S.; et al. Genetic ancestry and natural selection drive population differences in immune responses to pathogens. Cell 2016, 167, 657-669. [CrossRef] [PubMed]

87. Kwok, L.Y.; Zhang, J.; Guo, Z.; Gesudu, Q.; Zheng, Y.; Qiao, J.; Huo, D.; Zhang, H. Characterization of fecal microbiota across seven Chinese ethnic groups by quantitative polymerase chain reaction. PLoS ONE 2014, 9, e93631. [CrossRef] [PubMed]

88. Gomez, A.; Petrzelkova, K.J.; Burns, M.B.; Yeoman, C.J.; Amato, K.R.; Vlckova, K.; Modry, D.; Todd, A.; Robinson, C.A.J.; Remis, M.J.; et al. Gut microbiome of coexisting BaAka Pygmies and Bantu reflects gradients of traditional subsistence patterns. Cell Rep. 2016, 14, 2142-2153. [CrossRef] [PubMed]

89. Deschasaux, M.; Bouter, K.E.; Prodan, A.; Levin, E.; Groen, A.K.; Herrema, H.; Tremaroli, V.; Bakker, G.J.; Attaye, I.; Pinto-Sietsma, S.J.; et al. Depicting the composition of gut microbiota in a population with varied ethnic origins but shared geography. Nat. Med. 2018, 24, 1526-1531. [CrossRef] [PubMed]

90. Gaulke, C.A.; Sharpton, T.J. The influence of ethnicity and geography on human gut microbiome composition. Nat. Med. 2018, 24, 1459-1496. [CrossRef] [PubMed]

91. Soga, M.; Gaston, K.J.; Yamaura, Y.; Kurisu, K.; Hanaki, K. Both direct and vicarious experiences of nature affect children's willingness to conserve biodiversity. Int. J. Environ. Res. Public Health 2016, 13, 529. [CrossRef] [PubMed]

92. Hand, K.L.; Freeman, C.; Seddon, P.J.; Recio, M.R.; Stein, A.; van Heezik, Y. The importance of urban gardens in supporting children's biophilia. Proc. Natl. Acad. Sci. USA 2017, 114, 274-279. [CrossRef] [PubMed] 
93. Berg, G.; Köberl, M.; Rybakova, D.; Müller, H.; Grosch, R.; Smalla, K. Plant microbial diversity is suggested as the key to future biocontrol and health trends. FEMS Microbiol. Ecol. 2017, 93. [CrossRef] [PubMed]

94. Ma, B.D.; Ng, S.L.; Schwanen, T.; Zacharias, J.; Zhou, M.; Kawachi, I.; Sun, G. Pokémon GO and Physical Activity in Asia: Multilevel Study. J. Med. Internet Res. 2018, 20, e217. [CrossRef] [PubMed]

95. Mallon, C.A.; van Elsas, J.D.; Salles, J.F. Microbial invasions: The process, patterns.; mechanisms. Trends Microbiol. 2015, 23, 719-729. [CrossRef] [PubMed]

96. Urbina, H.; Breed, M.F.; Zhao, W.; Gurrala, K.L.; Andersson, S.G.; Ågren, J.; Baldauf, S.; Rosling, A. Specificity in Arabidopsis thaliana recruitment of root fungal communities from soil and rhizosphere. Fungal Biol. 2018, 122, 231-240. [CrossRef] [PubMed]

97. Latz, E.; Eisenhauer, N.; Rall, B.C.; Scheu, S.; Jousset, A. Unravelling linkages between plant community composition and the pathogen-suppressive potential of soils. Sci. Rep. 2016, 6, 23584. [CrossRef] [PubMed]

98. Mueller, U.G.; Sachs, J.L. Engineering microbiomes to improve plant and animal health. Trends Microbiol. 2015, 23, 606-617. [CrossRef] [PubMed]

99. Wallenstein, M.D. Managing and manipulating the rhizosphere microbiome for plant health: A systems approach. Rhizosphere 2017, 3, 230-232. [CrossRef]

100. Hussain, S.S.; Mehnaz, S.; Siddique, K.H. Harnessing the Plant Microbiome for Improved Abiotic Stress Tolerance. In Plant Microbiome: Stress Response; Springer: Singapore, 2018; pp. 21-43.

101. Van Heezik, Y.; Brymer, E. Nature as a commodity: What's good for human health might not be good for ecosystem health. Front. Psychol. 2018, 9, 1673. [CrossRef] [PubMed]

102. Capaldi, C.A.; Dopko, R.L.; Zelenski, J.M. The relationship between nature connectedness and happiness: A meta-analysis. Front. Psychol. 2014, 5, 976. [CrossRef] [PubMed]

103. Mayer, F.S.; Frantz, C.M.; Bruehlman-Senecal, E.; Dolliver, K. Why is nature beneficial? The role of connectedness to nature. Environ. Behav. 2009, 41, 607-643. [CrossRef]

104. Lumber, R.; Richardson, M.; Sheffield, D. Beyond knowing nature: Contact, emotion, compassion, meaning, and beauty are pathways to nature connection. PLoS ONE 2017, 12, e0177186. [CrossRef] [PubMed]

105. Bragg, R.; Atkins, G. A Review of Nature-Based Interventions for Mental Health Care (NECR204). Available online: http:/ / publications.naturalengland.org.uk/publication/4513819616346112 (accessed on 20 September 2018).

106. Van den Berg, A.E. From green space to green prescriptions: Challenges and opportunities for research and practice. Front. Psychol. 2017. [CrossRef] [PubMed]

107. Lovell, R.; Depledge, M.; Maxwell, S. Health and the Natural Environment: A Review of Evidence, Policy, Practice and Opportunities for the Future. 2018. Available online: https:/ / beyondgreenspace.net/2018/09/ 07/defra_health_review / (accessed on 21 September 2018).

108. Prescott, S.; Logan, A.C. The Secret Life of Your Microbiome: Why Nature and Biodiversity Are Essential to Health and Happiness; New Society Publishers: Gabriola Island, BC, Canada, 2017.

109. Albrecht, G. Ecopsychology in the Symbiocene. Ecopsychology 2014, 6, 58-59. [CrossRef]

(C) 2018 by the authors. Licensee MDPI, Basel, Switzerland. This article is an open access article distributed under the terms and conditions of the Creative Commons Attribution (CC BY) license (http://creativecommons.org/licenses/by/4.0/). 